Research Article

\title{
Complex Instruction Team Product (CITP) learning model: Improving student's scientific attitudes and learning outcomes
}

Dominggus Rumahlatu a,1, ${ }^{\text {, }}$ Kristin Sangur a,2, Sintje Liline a,3

a Study Program of Biology Education, Faculty of Teacher Training and Education, Universitas Pattimura, Jl. Ir. M. Putuhena, Ambon, Maluku 97233, Indonesia

1 dominggus_amq@yahoo.co.id*; ${ }^{2}$ sangur_kristin@yahoo.com; ${ }^{3}$ sinline28@yahoo.com

${ }^{*}$ Corresponding author

\begin{tabular}{|c|c|}
\hline ARTICLE INFO & ABSTRACT \\
\hline \multirow[t]{2}{*}{$\begin{array}{l}\text { Article history } \\
\text { Received May 03, } 2019 \\
\text { Revised May 25, } 2019 \\
\text { Accepted June 07, } 2019 \\
\text { Published June 30, } 2019 \\
\text { Keywords } \\
\text { Complex instruction } \\
\text { CITP learning model } \\
\text { Learning outcome } \\
\text { Scientific attitude } \\
\text { Team product }\end{array}$} & $\begin{array}{l}\text { Complex Instruction and Team Product (CITP) learning model is one of the creative- } \\
\text { innovative learning models which is assumed to be able to empower scientific attitudes } \\
\text { and learning outcomes of students. This study aimed to determine students' scientific } \\
\text { attitudes and cognitive learning outcomes by implementing CITP learning model. This } \\
\text { research used one-group pretest-posttest design. The sample was } 18 \text { tenth graders of } \\
\text { academic year } 2017 / 2018 \text { of State Senior High School } 6 \text { of Ambon, Maluku Province. } \\
\text { The data was analyzed using N-Gain test which then continued with dependent } \\
\text { samples t-test. This result indicated that the highest achievement of students' scientific } \\
\text { attitudes were honesty and creativity (54). Meanwhile, the N-Gain score of students' } \\
\text { cognitive learning outcomes was } 0.61 \text {. In addition, the results of paired samples t-test } \\
\text { show that there was a significant difference ( } p<0.05) \text { between the students' cognitive } \\
\text { learning outcomes before and after the application of CITP learning model. This means } \\
\text { that the application of CITP learning model can improve students' scientific attitudes } \\
\text { and cognitive learning outcomes. }\end{array}$ \\
\hline & $\begin{array}{l}\text { Copyright } \odot \text { 2019, Rumahlatu et al } \\
\text { This is an open access article under the CC-BY-SA license }\end{array}$ \\
\hline $\begin{array}{l}\text { Rumahla } \\
\text { studen } \\
\text { https:// }\end{array}$ & $\begin{array}{l}\text { \& Liline, S. (2019). Complex Instruction Team Product (CITP) learning model: Improvin } \\
\text { les and learning outcomes. JPBI (Jurnal Pendidikan Biologi Indonesia), 5(2), 207-216. do } \\
\text { pbi.v5i2.8367 }\end{array}$ \\
\hline
\end{tabular}

\section{INTRODUCTION}

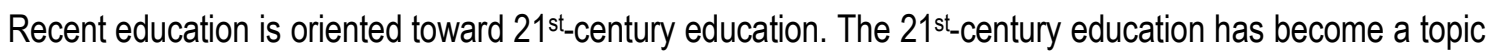
that has been discussed frequently (Binkley et al., 2014; Chu, Reynolds, Tavares, Notari, \& Lee, 2017; Johnson \& Johnson, 2014; Takeda, 2016). In this century human experiences fundamental changes compared to the previous century (Wijaya, Sudjimat, \& Nyoto, 2016). In order to be able to survive in the flow of life in the 21 st. century, education has to be able to guide students to develop their potential. Based on the results of the PISA survey (Program for International Student Assessment) in 2015, Indonesia ranks 62 out of 70 countries in the science field (PISA, 2015). Those data indicated that science learning in school institutions not been able to explore student's abilities such as cognitive, attitudes and psycho-motoric skills. Therefore, teachers must be 
able to design science learning that can accommodate cognitive abilities, attitudes, and psycho-motoric skills among students.

Several public high schools in Ambon city, Maluku, have implemented learning using creative-innovative learning models. Awan (2015) stated that role playing, one of cooperative learning model, can improve the learning outcomes of biology subject in the human digestive system concept. Hence, Johanis (2015) has applied the guided inquiry to improve student learning outcomes in the concept of the human respiratory system. In addition, Rumahlatu and Sangur (2017) implemented a Project-Based Learning strategy to improve metacognitive skills and understanding of biodiversity concept. Some biology teachers can adapt learning models to student material (Awan, 2015; Johanis, 2015; Rumahlatu \& Sangur, 2017). However, they have not used learning model that can accommodate students to have $21^{\text {st-century skills. }}$

Wagner (2016) identified several skills as indicators for $21^{\text {st }}$ century skills, namely: (1) critical thinking and problem solving skills, (2) collaboration and leadership, (3) agility and adaptability, (4) initiative and entrepreneurial spirit, (5) oral and written effective communication, (6) access ease and information analysis, and (7) broad curiosity and imagination. Trilling and Fadel (2009) illustrated 21st-century skills in the form of schemes consist of: (1) life and career skills, (2) learning and innovation skills, (3) information media and technology skills. Furthermore, Zubaidah (2016) explain the Delors Report in 1996 which is still relevant to the needs of the $21^{\text {st }}$ century, includes: (1) learning to know which is the development of a vision-oriented to the mastery skills, (2) learning to do which is oriented to critical thinking, problem-solving skills, communication and collaboration, creativity and innovation, information-media-technology literacy, and information-communicationtechnology (ICT) literacy, (3) learning to be which includes social skill, personal responsibility, and initiative, logical thinking skill, metacognitive skill, thinking skill in entrepreneurship, and learning for learning (lifelong learning), (4) learning to live together which consists of skills that value diversity, teamwork, and interconnectedness, civic and digital citizenship, as well as inter-cultural global competencies.

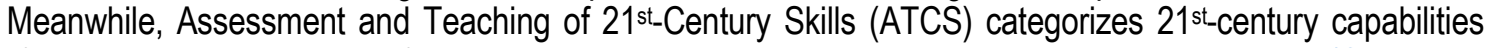
into four types, they are ways of thinking, how to work, tools to work and how to live in the world (Chu et al., 2017). Ball, Joyce, and Anderson-Butcher (2016) added in the 21 st-century pursuing students to improve careers development in the workforce and complex environments, such as leadership, time management, initiative, independence and collaboration skill. Some of the skills mentioned are indicators of scientific attitude.

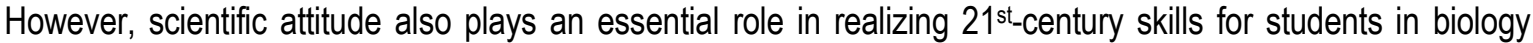
learning. According to Gauld and Hukins (1980) scientific attitude is complex of values and norms that must be possessed by a scientist. These norms are express in the form of prescriptions, proscriptions, preferences, and permissions (Gardner, 1975; Gauld \& Hukins, 1980; Mujtaba, Sheldrake, Reiss, \& Simon, 2018; Potvin \& Hasni, 2014). This attitude is used to provide an assessment of scientific action. Therefore, every scientific thought needs to be considered (Kristiani, Susilo, Rohman, \& Corebima Aloysius, 2015). A scientific attitude considered as a clear, natural logical way of thinking without any interference or prejudice, and the act of accepting facts or statements that have evidence (Candrasekaran, 2014). Nowadays, people's mindsets, opinions, and thoughts tend to be innovative and open-minded. The scientific attitudes consist of openmindedness, objectivity, rationality, and curiosity (Lacap, 2015). Therefore, scientific attitudes are demanded to make good and beneficial decisions for somebody lives.

Scientific attitude can be instilled in students through the learning process, which at the same time can also improve their learning outcomes. According to Samosir and Silitonga (2014), Cl learning model can improve student learning outcomes. $\mathrm{Cl}$ learning model can create conducive conditions for communication between students during discussion and learning (Pescarmona, 2014, 2017). The $\mathrm{Cl}$ learning model has the advantage of having a computational learning syntax. Nevertheless, at the end of learning, this strategy behaves not produce any product. Therefore, students only investigating without creating products. On the other hand, the Team Product (TP) method require the student to create products, such as scientific writing and threedimensional products. However, TP has weaknesses, namely the straightforward syntactic structure and the lack of techniques in the syntax. Seeing these condition, the $\mathrm{Cl}$ learning model assumed can cover the weakness of the TP method and vice versa.

The application of integrated models and learning methods is also expected to be able to improve the scientific attitude of students. The integration of the two learning models has been carried out by several previous researchers. Hariyadi, Corebima, Zubaidah, and Ibrohim (2018) integrate the Mind Mapping and RQA (Reading, Questioning, and Answering) learning model into a new stage, namely M-S-Q (Mind Mapping, Summarizing and Questioning). The results showed that M-S-Q provides a significant contribution to student learning outcomes. Listiana, Susilo, Suwono, and Suarsini (2016) combined Group Investigation (GI) and Think Talk and Write (TTW) learning strategies into Group Investigation-Think Talk Write (GITTW) which can mask the weakness of $\mathrm{Gl}$ strategy moreover can use as a variation in learning. Furthermore, the integration of the $\mathrm{Cl}$ and TP learning models is called CITP (Complex Instruction and Team Product). The application of the $\mathrm{Cl}$ 
learning model combined with the TP learning method is expected to contribute and provide learning conditions that are oriented towards the discovery and implementation of projects that create works/products in the form of quality goods or writing. The $\mathrm{Cl}$ learning model emphasizes the importance of implementing projects that are oriented toward discovery, while the TP method can be used by teachers to assign different roles or tasks to each group member to create a product.

The integration of $\mathrm{Cl}$ learning model and TP learning method assumed can be applied in the learning process, especially in ecosystem learning material. Students not only learn about the theory but also can practice in real life through investigation. Biology teachers in State Senior High School (SSHS) 6 Ambon have applied several learning models and methods, but they have not used the CITP learning model. The location of this school is close to the coastal region and forest ecosystem which can provide media for students to investigate the types and components of ecosystem. Thus, students can apply the theories to solve problems faced in everyday life. It is highly expected that through the application of this learning model, scientific attitudes and cognitive learning outcomes of students can be optimally empowered. This research is aimed to examine the application of CITP learning model in improving scientific attitudes and learning outcomes of tenth graders of SSHS 6 of Ambon. The CITP learning model is expected to support the learning process and empower cognitive learning outcomes as well as students' scientific attitudes to the ecosystem concept.

\section{METHOD}

This research used the one-group pretest-posttest design. The sample was 18 tenth graders of the academic year 2017/2018 of State Senior High School 6 of Ambon, Maluku Province. This research was conducted in SSHS 6 of Ambon, Maluku in the even semester of the 2017/2018 academic year. The instruments used to determine students' cognitive learning outcomes in the ecosystem topic was an essay test which applied before learning using CITP learning model (pre-test) and after learning (post-test). The other instrument was the observation sheet to find out the scientific attitudes of students during the learning process. The observation sheet was developed following scientific attitude indicators. Indicators of scientific attitudes assessed are curiosity, critical, diligent, creative, honest, open-minded and cooperative attitude (Candrasekaran, 2014; Kristiani et al., 2015).

A pre-test was conducted before the application of CITP learning. The learning process was carried out by following the syntax of the CITP learning model as follows: (1) The teacher prepares the learning material; (2) The teacher prepares a role card (facilitator, note-taker, recorder) for students; (3) The teacher divides students into groups; (4) The teacher instructs students to take role cards randomly and attach them to their chests; (5) The teacher delivers brief learning material; (6) The teacher instructs students to choose ideas according to the material being taught; (7) Students collect information; (8) The teacher instructs students to solve problems through discovery/investigation; (9) Students do creative works; (10) The teacher instructs students to present the product/work in front of the class; (11) During the discussion, the teacher observes student activities, records active and less active students, but the teacher may not answer student questions related to the material, the teacher may help groups of students if at the end the group is unable to answer.

To observe the student' scientific attitude, the assessment was carried out by observers during the learning process. Furthermore, the post-test was conducted upon the learning completion. The data was analyzed using $\mathrm{N}-$ Gain test (Formula 1).

$\mathrm{N}$ Gain $=\frac{\text { posttest score }- \text { pretest score }}{\text { maximum possible score }- \text { pretest score }}$

The average value of scientific attitudes during the learning process was visualized in graphical form. The result of $\mathrm{N}$-Gain then categorized based on the Hake Formula, as seen as at Table 1 (Archambault, Burch, Crofton, \& Mcclure, 2008; Meltzer, 2002).

Table 1. N-Gain value result category

\begin{tabular}{cc}
\hline Limit & Category \\
\hline$g>0.7$ & High \\
$0.3<g \leq 0.7$ & Moderate \\
$g \leq 0.3$ & Low \\
\hline
\end{tabular}

The data of pre-test and post-test were analyzed using dependent samples t-test. The prerequisite test used was the Kolmogorov-Smirnov test to determine the normality of the data and the Levene test to determine 
the homogeneity of data. Dependent samples t-test was used to analyze differences in cognitive learning outcomes of students before and after the application of CITP learning model.

\section{RESULTS AND DISCUSSION}

\section{Students' scientific attitudes}

Scientific attitudes play an important role in science learning. In studying the ecosystem concept, tenth graders of SSHS 6 Ambon can develop scientific attitude well. Creativity and honest attitudes had highest scores compared to other attitudes (Figure 1). This finding proves that the product of one group was different from other groups. The student can add new combinations and elements in the product to produce new investigative products (Tombak \& Altun, 2016). Investigative syntax helps develop perseverance, creativity, and discovery. Through the right scientific attitude, students are allowed to develop a good character that will contribute positively to the scientific culture in society (Lacap, 2015). The improvement in the indicator of students' scientific attitudes was influenced by the syntax of the CITP learning model. According to Hayat, Anggraeni, and Redjeki (2011) changes in students' scientific attitudes after learning showed that a person's attitude is not static but dynamically change due to the learning process. The syntax of "role card" sharing at the beginning of learning made students aware and at the same time familiarized them to develop cooperative teamwork.

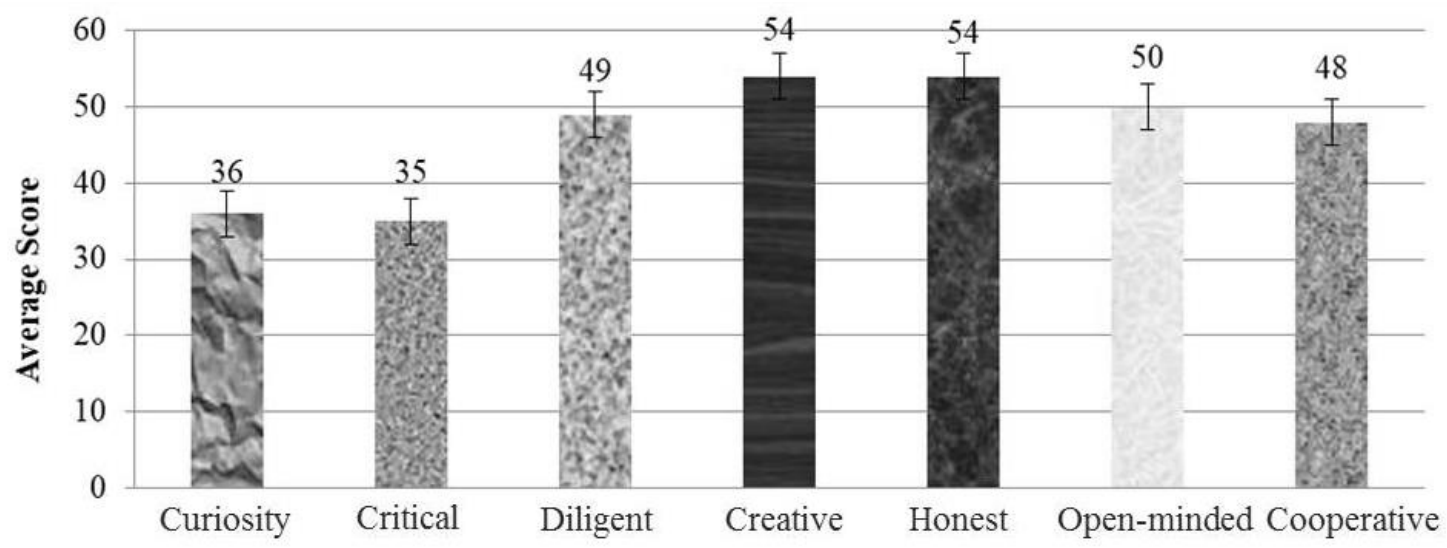

\section{Scientific Attitudes Category}

Figure 1. Students' scientific attitude scoring in SSHS 6 of Ambon

Critical attitude gained the lowest score among the students' scientific attitudes (Figure 1). It shows that in the learning process students were not able to analyze and evaluate information during investigation and discussion. Students' curiosity attitude obtained an average score of 36 points (Figure 1) indicates that students' ability to choose ideas and express questions or problems are still low and this require the teachers to act as a facilitator to foster students curiosity. When learning with the application of syntax for choosing ideas and gathering information, students can develop an attitude of curiosity. In line with Widiadnyana, Sadia, and Suastra (2014) study that the emergence of curiosity to investigate concepts and the demands of exploration will certainly direct students' thinking to understand the problems as the topic of learning.

The cooperative attitude with an average score of 48 points (Figure 1) indicates that students collaborated to carry out the process of investigating ecosystems in groups. The $\mathrm{Cl}$ learning model forces student to participate in cooperative activities (Pescarmona, 2014). While the diligent attitude was reaching the average score 49 points (Figure 1). It shows that the learning model can encourage students to be serious in the learning process and carry out the investigation process. Moreover, open-minded attitude with an average score of 50 (Figure 1) points portrays that students can receive opinions and criticisms from other friends without feeling offended. Marchis (2011) reported that there is an influence between students' self-efficacy and student attitudes in learning and students' positive behavior in seeking help. Attitudes towards the willingness to learn science are vital parameters for generating students' confidence (Erdogan, 2017). Therefore, the division of tasks on the "role card" is beneficial for students in fostering an attitude of cooperation in the team.

The syntax of presenting products helps develop an honest, open-minded and critical attitude. A scientist needs to be objective in gathering and interpreting ideas and communicating findings honestly. Some more scientist need to have critical thinking that is behaving in search of evidence and arguments in supporting other 
people's statements (Pitafi \& Farooq, 2012). The attitude of objectivity or openness refers to an attitude to observe facts without any personal influence, bias or ambition in interpreting the results of observations (Sharma, 2016). Students 'scientific attitudes are obtained through the learning process that takes place and is influenced by environmental factors, interactions with people around students, students' families, student groups, friends and aspirations from students themselves (Papanastasiou \& Papanastasiou, 2004).

\section{Student cognitive learning outcome $N$-Gain test}

The students' cognitive learning outcome was measured using an essay test. The differences in the results of the pre-test and post-tests were then calculated by using the N-Gain test. The students' scores are shown in Figure 2, while the N-gain results are shown in Table 2.

$$
\text { are Test }=\text { Post Test }
$$

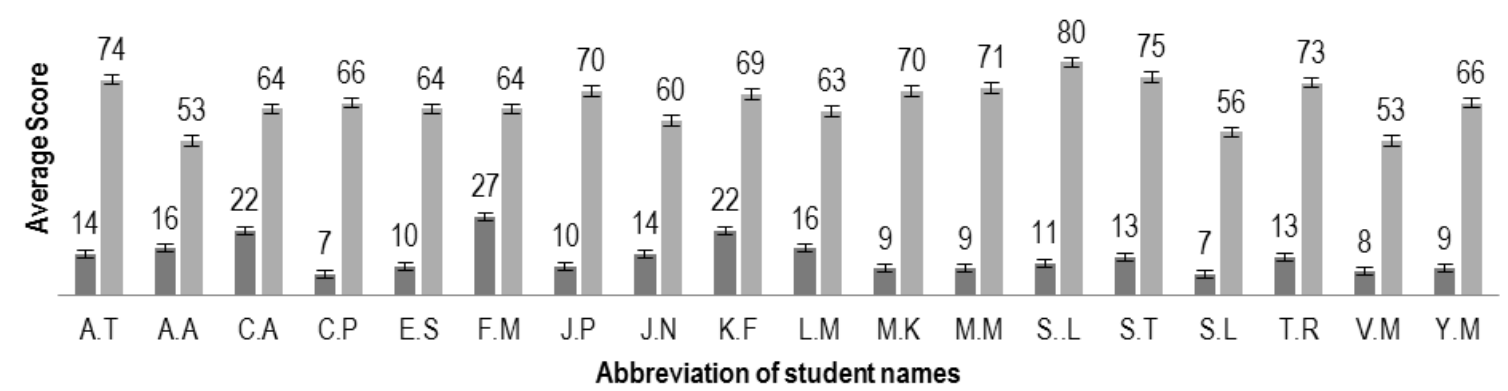

Figure 2. Pre-test, post-test and Gain values of SSHS 6 of Ambon students

The results showed that the distribution of the pre-test scores of all students was in a low category, but after the application of the CITP learning model, the post-test results of cognitive learning were increased (Figure 2). After calculating the $\mathrm{N}$-Gain test, it was known that the minimum N-Gain was 0.44 , while the maximum N-Gain was 0.775 (Table 2). The average $\mathrm{N}$-gain value of students in this ecosystem concept was 0.61 ; thus, concluded as the moderate category. Students' success in learning could be seen through the learning outcomes. One of the learning outcomes measured in this study is cognitive learning outcome. The cognitive learning outcome which is associated with students' understanding of ecosystem concepts is formed through the learning process using the CITP. According to Ramdiah and Corebima (2014), the learning process is developed to influence students' thinking abilities, which can then improve their academic achievement.

Table 2. N-Gain of tenth grader SSHS 6 of Ambon

\begin{tabular}{ccc}
\hline No. & Abbreviation of student name & N-Gain \\
\hline 1 & A.T. & 0.698 \\
2 & A.A. & 0.44 \\
3 & C.A. & 0.538 \\
4 & C.P. & 0.634 \\
5 & E.S. & 0.6 \\
6 & E.M. & 0.507 \\
7 & J.P. & 0.667 \\
8 & J.N. & 0.535 \\
9 & K.F. & 0.603 \\
10 & L.M. & 0.56 \\
11 & M.K. & 0.67 \\
12 & M.M. & 0.681 \\
13 & S.L. & 0.775 \\
14 & S.T. & 0.713 \\
15 & S.L. & 0.527 \\
16 & T.R. & 0.69 \\
17 & V.M. & 0.489 \\
18 & Y.M. & 0.626 \\
\hline
\end{tabular}




\section{Classical assumption test}

The result of the Kolmogorov-Smirnov test shows that the data has a normal distribution (Table 3). Meanwhile, the Levene test revealed that data came from a homogeneous population (Table 4). Therefore, the data can be analyzed using dependent sample t-test.

Table 3. The result of Kolmogorov-Smirnov test (normality)

\begin{tabular}{cccc}
\hline & \multicolumn{3}{c}{ Kolmogorov-Smirnov $^{\mathrm{a}}$} \\
\cline { 2 - 4 } & Statistic & $d f$ & Sig. \\
\hline Pre test & .164 & 18 & $.200^{*}$ \\
Post test & .114 & 18 & $.200^{*}$ \\
\hline
\end{tabular}

Table 4. The result of Levene test (homogeneity)

\begin{tabular}{lcccc}
\hline & Levene Statistic & df1 & df2 & Sig. \\
\hline Based on Mean & 1.330 & 1 & 34 & .257 \\
Based on Median & 1.281 & 1 & 34 & .266 \\
Based on Median and with adjusted df & 1.281 & 1 & 33.033 & .266 \\
Based on trimmed mean & 1.363 & 1 & 34 & .251 \\
\hline
\end{tabular}

\section{Hypothesis testing}

Dependent sample t-test was conducted to test statistically whether there are differences in student cognitive learning outcomes before and after the application of CITP learning model, the test result can be seen in Table 5.

Table 5. The results of dependent sample t-test

\begin{tabular}{cccccccc}
\hline \multicolumn{1}{c}{ Mean } & \multirow{2}{*}{ Std. Deviation } & \multirow{2}{*}{ Std. Error Mean } & \multicolumn{2}{c}{ P5\% Confidence Interval of the Difference } & \multirow{2}{*}{$\mathrm{t}$} & \multirow{2}{*}{ df } & \multirow{2}{*}{ Sig. (2-tailed) } \\
\cline { 3 - 7 } & & & Lower & Upper & & & \\
\hline-53.00000 & 9.44333 & 2.22581 & -57.69606 & -48.30394 & -23.812 & 17 & $<0.05$ \\
\hline
\end{tabular}

Based on Table 5, the dependent sample t-test has a significant 2-tailed $<\alpha(0.05)$. This shows that there are differences in student cognitive learning outcomes before and after the application of the CITP learning model on ecosystem topic. The CITP learning model can empower students' cognitive thinking skills in studying ecosystem material so that there will be a change in cognitive thinking before and after the application of the CITP learning model. The process of student cognitive formation begins in the syntax of gathering information to prepare for investigative activities. Listiana et al. (2016) argue that information gathering syntax is one of the crucial stages in conducting an investigation. When collecting information, students read and learn from various kinds of literature. Reading activities carried out by students will be meaningful if students read in the literature that is appropriate and recommended to be read (Hariyadi et al., 2018). After that, in the syntax of problem-solving through investigation, students will encounter real conditions and connect the theories that have been studied previously with the real conditions that students observe. This is related to contextual learning and meaningful learning. During the investigation process in various ecosystems, students can observe the components and interactions between components in the ecosystem. Rumahlatu and Sangur (2017) conveys that through the observation and survey learning process in the environment, students try to associate concepts from various scientific disciplines and contextual experiences to enrich the concepts that they already have so that they form a new understanding of concepts.

Through meaningful learning, there is the potential to increase students' knowledge and skills in learning (Ünal \& Özdemir, 2013). Prayekti (2018) explained that the learning process provided behavioral changes to students due to individual experiences and their interactions with their environment. The results of the studies are in line with several previous studies which also used modified cooperative learning and influenced the increase in cognitive learning outcomes (Gunawan, A Harjono, H Sahidu, \& Nisrina, 2018; Hariyadi et al., 2018; Husamah \& Pantiwati, 2014; Listiana et al., 2016; Yaqin, Indriwati, \& Susilo, 2018). The learning process can shape students' cognitive understanding of the concept of ecosystems. Next syntax, students who present their work would find a structure of thinking that continues to grow because there is additional knowledge from other students during communication. According to Leasa and Corebima (2017) students share experiences with others when they are communicating and in the end students solve the problem together. 
Through the stages of the CITP learning model, students can form information and store in their cognitive structure. This is in line with Lestari, Wardani, and Sumarti (2018) study that conventional learning does not make students active in responding to learning so student's cognitive learning outcomes are low, but if students experience the learning process finding concepts through gathering information and making conclusions, students can transfer their knowledge to gain new knowledge through the help of teachers. The stages in the CITP learning model are students choosing ideas, gathering information through investigation and solving problems through the manufacture of products, so students can form new knowledge through constructive activities. Dunlosky, Rawson, Marsh, Nathan, and Willingham (2013) added that the empowerment of student's cognitive skills that increase can make it easier for students to display how students associate learned concepts with life experiences and are more flexible in expressing many ideas. The cognitive skills can be improved through way learn how to learn (Listiana et al., 2016). In this way, students can understand the stages of CITP learning and can experience a good learning environment.

\section{CONCLUSION}

The application of the CITP learning model can improve students' scientific attitudes. This is proved by the score of each scientific attitude indicators, namely critical (35 points), curiosity (36 points), cooperative (48 points), diligent (49 points), open-minded (50 points), honest (54 points), and creative (54 points). Besides, the application of the CITP learning model can improve the cognitive learning outcomes of students tested using the $\mathrm{N}$-gain test of 0.61 and thus included in the medium category. Meanwhile, through dependent sample t-test, it was found that there were significance differences in cognitive learning outcomes before and after the application of the CITP model. This shows that the cognitive structure of students before and after the application of the CITP learning model brought a lot of changes. The information obtained from the results of this study is the new learning syntax due to the CITP learning model, thus biology teachers can use this CITP model in teaching ecosystem concept to improve scientific attitudes and cognitive learning outcomes of students. The results of this study will also inspire other researchers who wish to apply the CITP model to other biological concepts.

\section{ACKNOWLEDGMENT}

The authors express their gratitude to the Faculty of Teacher Training and Education, Universitas Pattimura for providing research grant through the Social, Humanities, and Education Research Grant in the 2018 budget year with the Decree No. 955/UN13/SK /2018 dated July 10, 2018.

\section{REFERENCES}

Archambault, J., Burch, T., Crofton, M., \& Mcclure, A. (2008). The effects of developing kinematics concepts graphically prior to introducing algebraic problem solving techniques. Retrieved from http://modeling. asu.edu/modeling/Kinematics-graphical08brief.pdf

Awan, A. (2015). Peranan model pembelajaran kooperatif tipe role playing menggunakan sistem pencernaan makanan pada manusia di Kelas XI IPA SMA Negeri 9 Kota Ambon. Biopendix: Jurnal Biologi, Pendidikan Dan Terapan, 1(2), 166-169. Retrieved from https://ejournal.unpatti.ac.id/ppr_iteminfo_Ink. php?id=1126

Ball, A., Joyce, H. D., \& Anderson-Butcher, D. (2016). Exploring 21st century skills and learning environments for middle school youth. International Journal of School Social Work, 1(1), 1-15. doi: https://doi.org/10.4 148/2161-4148.1012

Binkley, M., Erstad, O., Herman, J., Raizen, S., Ripley, M., Miller-Ricci, M., \& Rumble, M. (2014). Defining twenty-first century skills. In Assessment and teaching of 21st century skills. doi: https://doi.org/10. 1007/978-94-007-2324-5_2

Candrasekaran, S. (2014). Developing scientific attitude, critical thinking and creative intelligence of higher secondary school biology students by applying synectics techniques. International Journal of Humanities and Social Science Invention, 3(6), 1-8. Retrieved from http://www.ijhssi.org/papers/v3(6)/ Version-2/A03620108.pdf

Chu, S. K. W., Reynolds, R. B., Tavares, N. J., Notari, M., \& Lee, C. W. Y. (2017). 21st Century skills development through inquiry-based learning. Singapore: Springer Singapore. doi: https://doi.org/10. 1007/978-981-10-2481-8 
Dunlosky, J., Rawson, K. A., Marsh, E. J., Nathan, M. J., \& Willingham, D. T. (2013). Improving students' learning with effective learning techniques: Promising directions from cognitive and educational psychology. Psychological Science in the Public Interest, 14(1), 4-58. doi: https://doi.org/10.1177/15291 00612453266

Erdogan, S. C. (2017). Science teaching attitudes and scientific attitudes of pre-service teachers of gifted students. Journal of Education and Practice, 8(6), 164-170. Retrieved from https://files.eric.ed.gov/full text/EJ1133039.pdf

Gardner, P. L. (1975). Attitudes to science : A review. Studies in Science Education, 2(1), 1-41. doi: https:// doi.org/10.1080/03057267508559818

Gauld, C. F., \& Hukins, A. A. (1980). Scientific attitudes: A review. Studies in Science Education, 7(1), 129161. doi: https://doi.org/10.1080/03057268008559877

Gunawan, A Harjono, H Sahidu, \& Nisrina. (2018). Improving students' creativity using cooperative learning with virtual media on static fluida concept. In International Conference on Science Education (ICoSEd) . IOP Publishing. doi: https://doi.org/10.1088/1742-6596/1006/1/012016

Hariyadi, S., Corebima, A. D., Zubaidah, S., \& Ibrohim. (2018). Contribution of mind mapping, summarizing, and questioning in the RQA learning model to genetic learning outcomes. Journal of Turkish Science Education (TUSED), 15(1), 80-88. doi: https://doi.org/10.12973/tused.10222a

Hayat, M. S., Anggraeni, S., \& Redjeki, S. (2011). Pembelajaran berbasis praktikum pada konsep invertebrata untuk pengembangan sikap ilmiah siswa. Bioma: Jurnal Ilmiah Biologi, 1(2), 141-152. Retrieved from http://journal.upgris.ac.id/index.php/bioma/article/view/352/306

Husamah, \& Pantiwati, Y. (2014). Cooperative learning STAD-PjBL: Motivation, thinking skills, and learning outcomes of Biology Department students. International Journal of Education Learning and Development, 2(1), 77-94. Retrieved from https://www.eajournals.org/journals/international-journal-ofeducation-learning-and-development-ijeld/vol-2-issue-1-march-2014/cooperative-learning-stad-pjbl-moti vation-thinking-skills-learning-outcomes-biology-department-students/

Johanis, L. (2015). Penerapan strategi guided inquiry untuk meningkatkan hasil belajar siswa Ambon konsep sistem pernapasan manusia Kelas XI SMA Negeri 12 Ambon. Biopendix : Jurnal Biologi, Pendidikan Dan Terapan, 1(2), 179-187. Retrieved from https://ojs3.unpatti.ac.id/index.php/biopendix/article/view/ 997

Johnson, D. W., \& Johnson, R. T. (2014). Cooperative learning in 21st century. Anales De Psicología / Annals of Psychology, 30(3), 841-851. doi: https://doi.org/10.6018/analesps.30.3.201241

Kristiani, N., Susilo, H., Rohman, F., \& Corebima Aloysius, D. (2015). The contribution of students' metacognitive skills and scientific attitude towards their academic achievements in biology learning implementing Thinking Empowerment by Questioning (TEQ) learning integrated with inquiry learning (TEQI). International Journal of Educational Policy Research and Review, 2(9), 113-120. doi: https:/l doi.org/10.15739/IJEPRR.020

Lacap, M. P. (2015). The scientific attitudes of students major in science in the new teacher education curriculum. Asia Pacific Journal of Multidisciplinary Research, 3(5), 7-15. Retrieved from http://www. apjmr.com/wp-content/uploads/2016/04/APJMR-2015-3.5.3.02.pdf

Leasa, M., \& Corebima, A. D. (2017). The effect of numbered heads together (NHT) cooperative learning model on the cognitive achievement of students with different academic ability. In J. Phys.: Conf. Ser. (Vol. 795, pp. 1-9). IOP Publishing. doi: https://doi.org/10.1088/1742-6596/795/1/012071

Lestari, P., Wardani, S., \& Sumarti, S. S. (2018). Influence of Guided Inquiry Model on students cognitive learning outcome in stoichiometry topic. Journal of Innovative Science Education, 7(2), 130-135. doi: https://doi.org/10.15294/JISE.V7|2.23853

Listiana, L., Susilo, H., Suwono, H., \& Suarsini, E. (2016). Contributions of metacognitive skills toward students' cognitive abilities of biology through the implementation of GITTW (Group Investigation combined with Think Talk Write) strategy. In Proceeding of International Conference on Teacher Training and Education (ICTTE) FKIP UNS 2015 (Vol. 1, pp. 411-418). FKIP Universitas Sebelas Maret. Retrieved from https://jurnal.fkip.uns.ac.id/index.php/ictte/article/view/7638

Marchis, I. (2011). Factors that influence secondary school students' attitude to mathematics. Procedia-Social and Behavioral Sciences, 29, 786-793. doi: https://doi.org/10.1016/j.sbspro.2011.11.306

Meltzer, D. E. (2002). The relationship between mathematics preparation and conceptual learning gains in physics: A possible "hidden variable"' in diagnostic pretest scores. Am. J. Pyhs., 70(12), 1259-1268. doi: https://doi.org/10.1119/1.1514215 
Mujtaba, T., Sheldrake, R., Reiss, M. J., \& Simon, S. (2018). Students' science attitudes, beliefs, and context: associations with science and chemistry aspirations. International Journal of Science Education, 40(6), 644-667. doi: https://doi.org/10.1080/09500693.2018.1433896

Papanastasiou, C., \& Papanastasiou, E. C. (2004). Major influences on attitudes toward science. Educational Research and Evaluation, 10(3), 239-257. doi: https://doi.org/10.1076/edre.10.3.239.30267

Pescarmona, I. (2014). Learning to participate through Complex Instruction. Intercultural Education, 25(3), 187-196. doi: https://doi.org/10.1080/14675986.2014.905360

Pescarmona, I. (2017). Reflexivity-in-action: How complex instruction can work for equity in the classroom. Journal of Education for Teaching, 43(3), 328-337. doi: https://doi.org/10.1080/02607476.2017.13195 08

PISA. (2015). Draft science framework. Retrieved from https://www.oecd.org/pisa/pisaproducts/Draft PISA 2015 Science Framework .pdf

Pitafi, A. I., \& Farooq, M. (2012). Measurement of scientific attitude of secondary school students in Pakistan. Academic Research International, 2(2), 379-392. Retrieved from www.savap.org.pkwww.journals.sav ap.org.pk

Potvin, P., \& Hasni, A. (2014). Interest, motivation and attitude towards science and technology at K-12 levels: a systematic review of 12 years of educational research. Studies in Science Education, 50(1), 85-129. doi: https://doi.org/10.1080/03057267.2014.881626

Prayekti. (2018). The influence of cognitive learning style and learning independence on the students' learning outcomes. Higher Education Studies, 8(2), 37-46. doi: https://doi.org/10.5539/hes.v8n2p37

Ramdiah, S., \& Corebima, A. D. (2014). Learning strategy equalizing students' achievement, metacognitive, and critical thinking skills. American Journal of Educational Research, 2(8), 577-584. doi: https://doi. org/10.12691/education-2-8-3

Rumahlatu, D., \& Sangur, K. (2017). Implementation of project-based learning strategies to improve metacognitive skills and understanding of biodiversity concepts in State High School 2 Kairatu, West District of Seram. In Proceeding the 2nd International Seminar on Education (Vol. 1, pp. 43-48). Ambon. Retrieved from https://ojs.unpatti.ac.id/index.php/ises/article/view/127

Samosir, F. S., \& Silitonga, M. (2014). Penerapan pembelajaran kooperatif tipe pengajaran kompleks (Complex Intruction) dalam pembelajaran kompetensi menganalisis rangkaian kemagnetan. Universitas Negeri Medan. Retrieved from http://digilib.unimed.ac.id/1052/3/FullText.pdf

Sharma, U. (2016). A comparative study of scientific attitude of science and non-science B.T.C. pupil teachers. International Journal of Applied Research, 2(6), 612-615. Retrieved from http://www.allre searchjournal.com/archives/2016/vol2issue6/PartJ/2-5-17-944.pdf

Takeda, I. (2016). Report: Project-based learning with 21st century skills for the Japanese language classroom. Journal of Integrated Creative Studies. Retrieved from http://www2.yukawa.kyoto-u.ac.jp/ future/wp-content/uploads/2017/12/2016-020-e.pdf

Tombak, B., \& Altun, S. (2016). The effect of cooperative learning: University example. Eurasian Journal of Educational Research, (64), 173-196. doi: https://doi.org/10.14689/ejer.2016.64.10

Trilling, B., \& Fadel, C. (2009). 21st century skills: Learning for life in our times. San Francisco, CA, US: Jossey-Bass. Retrieved from https://psycnet.apa.org/record/2009-18745-000

Ünal, C., \& Özdemir, Ö. F. (2013). A physics laboratory course designed using problem-based learning for prospective physics teachers. European Journal of Science and Mathematics Education, 1(1), 29-33. Retrieved from http://www.acarindex.com/dosyalar/makale/acarindex-1423880574.pdf

Wagner, T. (2016). The Global Achievement Gap. Retrieved August 2, 2019, from https:/leducation.uky.edu/ nxgla/wp-content/uploads/sites/33/2016/11/The-Global-Achievement-Gap-7-Survival-Skills-.pdf

Widiadnyana, I. W., Sadia, I. W., \& Suastra, I. W. (2014). Pengaruh model discovery learning terhadap pemahaman konsep IPA dan sikap ilmiah siswa SMP. Jurnal Pendidikan Dan Pembelajaran IPA Indonesia, 4(1), 1-13. Retrieved from http://oldpasca.undiksha.ac.id/e-journal/index.php/jurnal_ipa/art icle/view/1344/1036

Wijaya, E. Y., Sudjimat, D. A., \& Nyoto, A. (2016). Transformasi pendidikan Abad 21 sebagai tuntutan pengembangan sumber daya manusia di Era Global. In Prosiding Seminar Nasional Pendidikan Matematika 2016 (Vol. 1, pp. 263-278). Malang: Universitas Kanjuruhan Malang. Retrieved from http://repository.unikama.ac.id/840/32/263-278 TRANSFORMASI PENDIDIKAN ABAD 21 SEBAGAI TUNTUTAN PENGEMBANGAN SUMBER DAYA MANUSIA DI ERA GLOBAL.pdf 
Yaqin, M. A., Indriwati, S. E., \& Susilo, H. (2018). Think-pair-square learning: Improving student's collaborative skills and cognitive learning outcome on animal diversity course. Jurnal Pendidikan Biologi Indonesia, 4(2), 135-142. doi: https://doi.org/10.22219/jpbi.v4i2.5514

Zubaidah, S. (2016). Keterampilan abad ke-21: Keterampilan yang diajarkan melalui pembelajaran. In Seminar Nasional Pendidikan dengan tema "Isu-Isu Strategis Pembelajaran MIPA Abad 21" (pp. 1-17). Sintang-Kalimantan Barat: Program Studi Pendidikan Biologi STKIP Persada Khatulistiwa. Retrieved from https://www.researchgate.net/publication/318013627_KETERAMPILAN_ABAD_KE-21_KETERAM PILAN_YANG_DIAJARKAN_MELALUI_PEMBELAJARAN 